Journal of Animal and Veterinary Advances 9 (18): 2343-2345, 2010

ISSN: $1680-5593$

(C) Medwell Journals, 2010

\title{
Long Term Used Testosterone May Cause Heart and Liver Damage
}

\author{
${ }^{1}$ Sefa Lok, ${ }^{2}$ Erdal Tasgin, ${ }^{3}$ Nagehan Demir and ${ }^{1}$ Mehmet Ozdemir \\ ${ }^{1}$ Academy of Physical Education and Sports, Selcuk University, 42075, Konya, Turkey \\ ${ }^{2}$ Health Science Institute, Selcuk University, 42075, Konya, Turkey \\ ${ }^{3}$ Department of Biochemistry, Faculty of Veterinary, Selcuk University, 42075, Konya, Turkey
}

\begin{abstract}
The purpose of the research is to define the effects of testosterone on heart, liver, kidney and some chemical values in male rats during puberty. In the research 16 Sprague dawley rats, 50 days old were used. The rats were divided into two equal groups. The first group was administrated testosterone, diluted with olive oil, $5 \mathrm{mg} \mathrm{kg}^{-1}$ (SID) subcutaneously for 10 weeks 5 days each week. The second group was only given olive oil. At the end of the 10th week blood samples were taken. Serum creatine kinase, creatine kinase-MB, alkaline phosphatase, alanine aminotransferase, aspartate aminotransferase, blood urea nitrogen, creatinine, triglyceride, cholesterol, high density lipoprotein, amylase, total protein, albumin and calcium were measured with an auto-analyzer. It was determined that while testosterone application in male rats led to increase on the serum CK-MB, CK and AST levels ( $<<0.05$ ), it caused decreases on the total protein, albumin, calcium and creatinine $(\mathrm{p}<0.05)$. As a result, it can be stated that long term testosterone implication during puberty may lead to heart and liver defects at early ages.
\end{abstract}

Key words: Testosterone, creatine kinase, creatine kinase-MB, aspartate aminotransferase, albumen, serum

\section{INTRODUCTION}

Testosterone hormone was first defined as sex hormone by David as testos=testes, ster=sterol and one $=$ ketone (Handelsman, 2006; Dotson and Brown, 2007).

In men, testosterone is produced in the leydig cell of the testis (Hartgens and Kuipers, 2004) and it functions in the development of secondary sex characters (voice thickening, increase in power and hairing), release of gonadotropin and functions anabolically in the stimulation of protein synthesis (Wu, 1997; Hartgens and Kuipers, 2004). Testosterone is found in the body in three forms as free, SHBG (Sex Hormone-binding Globulin) and those that are impotently binded to albumin or cortisol binding globulin (Bukowski et al., 2000).

When testosterone is taken orally or paranterally, it is rapidly metabolized. However, Anabolic Androgenic Steroids (AAS), synthetic derivations of testosterone, are given orally or intravenously due to the difference of ester groups in their structures (Vardar et al., 2002). Clinically testosterone and AASs are used for the treatment of renal failure, anemia, growing deficiency in children, delayed puberty and in case of some chronic weakness such as AIDS and cancer (Marshall-Grandisnik et al., 2009). The clinical usage of testosterone for the control of excessive weight loss related to AIDS has increased $400 \%$ since 1985 (Kerr and Congeni, 2007). Though AAS usage is more frequently seen in men, it has been reported that the usage among young females is on the increase (Vardar et al., 2002). It was reported that 1-2\% of young females and $4-6 \%$ of young males used AAS at least once in 2001 (Marshall-Grandisnik et al., 2009). It has been reported that young people start using testosterone at the age of 16 and research conducted on the issue show that the reason for using this medicine is that they want to have a muscular body and increase their sportive performance (Vardar et al., 2002).

It has been reported that according to the test results of international anti-doping agency (WADA) elite sportsmen also abused AAS and the most frequently used medicines were reported to be testosterone, nandrolon and stanazolol (Handelsman, 2006). In a research conducted to define AAS abuse among high school students, it was reported that abuse frequency increased as parallel to socio economic condition (Handelsman and Gupta, 1997).

Uncontrolled usage of testosterone derivations may lead to serious side effects such as cardiovascular system disorders, lipid metabolism disorders or insulin sensitivity. In addition when used as performance enhancing agent, it can cause ethical problems (Bhasin et al., 1996). The most common side effects of AAS are increase in the atherosclerosis, tachycardia, cardiac hypertrophy, cardiac function disorder, sudden death, depression, agressiveness, behaviour disorder, muscle sores, nausea,

Corresponding Author: Sefa Lok, Academy of Physical Education and Sports, Selcuk University, 42075, Konya, Turkey 
vomit, testicular atrophy and liver injury (Casavant et al., 2007; Marshall-Grandisnik et al., 2009). Biochemical values measured from serum give information on some organ and system defects in living organisms. Creatine kinase-MB (CK-MB) is defined as heart injury indicator, creatine kinase as muscle injury indicator (Dickerman et al., 1999), Alkaline Phosphatase (ALP), Alanine Aminotransferase (ALT), Aspartat Aminotransferase (AST) and Gamma Glutamyl Transferase (GGT) are defined as liver injury indicators, urea (BUN) and creatinine are defined as renal injury indicators, triglyceride, cholesterol and High Density Lipoprotein (HDL) levels are indicators of lipid metabolism (Bartley, 1989; Kramer, 1989; Finco, 1989). Amylase is a marker of carbohydrate metabolism while total protein and albumin is indicators of protein metabolism. Calcium (Ca) is the indicators of fluid-electrolyte balance as well. In the literature, no information on the effects of long term testosterone usage during puberty on serum biochemical values has been encountered. The purpose of the research is to define the effects of testosterone on heart, liver, kidney injury indicators and some routine biochemical values in male rats during puberty.

\section{MATERIALS AND METHODS}

In the research, 16 Sprague dawley male rats ( 50 days old, SUDAM, Konya, Turkey) were used. The research was approved by the ethical committee of Veterinary Faculty. The rats were divided into two groups equally. The first group was administrated testosterone (Sustanon $^{7} 250$ amp), diluted with olive oil, $5 \mathrm{mg} \mathrm{kg} \mathrm{kg}^{-1}$ (SID) subcutaneously for 10 weeks 5 days (Saturday and Sunday resting) each week. The second group was given only olive oil. The subjects were fed during the experiment as ad libitum. They were sheltered at $25^{\circ} \mathrm{C}$ and $5200 \% \mathrm{Rh}$ humid conditions. At the end of the 10 weeks, blood samples were taken from heart under pentabarbital anesthesia and then the subjects were euthanized. Serum $\mathrm{CK}, \mathrm{CK}-\mathrm{MB}$, ALP, ALT, AST, BUN, creatinine, triglyceride, cholesterol $\mathrm{HDL}$, amylase, total protein, albumin and calcium levels were measured with an auto-analyzer (IL-300 Instrumentation Laboratory Milano, Italy). The results of the research were evaluated with paired t-test (SPSS 10.0), p<0.05 was accepted statistically significant.

\section{RESULTS AND DISCUSSION}

The effect of testosterone on serum biochemical values of rats were shown in Table 1. It was determined that while testosterone decreased total serum protein,
Table 1: Biochemical values of testosterone applied male rats (mean $\pm \mathrm{SEM}$ ) \begin{tabular}{lll}
\hline Parameters & Olive oil & Testosteron \\
\hline
\end{tabular} $\mathrm{CK}\left(\mathrm{UL}^{-1}\right)$ CK-MB $\left(\mathrm{U} \mathrm{L}^{-1}\right)$

$\operatorname{ALT}\left(\mathrm{UL}^{-1}\right)$

$\operatorname{AST}\left(\mathrm{UL}^{-1}\right)$

$\operatorname{ALP}\left(\mathrm{U} \mathrm{L}^{-1}\right)$

BUN (mg dL ${ }^{-1}$

Creatinine $\left(\mathrm{mg} \mathrm{dL}^{-1}\right)$

Triglyceride $\left(\mathrm{mg} \mathrm{dL}^{-1}\right)$

Cholesterol $\left(\mathrm{mg} \mathrm{dL}^{-1}\right)$

HDL $m g ~ d L^{-1}$ )

Amylase $\left(\mathrm{UL} \mathrm{L}^{-1}\right)$

Total protein $\left(\mathrm{g} \mathrm{dL}^{-1}\right)$

Albumin $\left(\mathrm{g} \mathrm{dL}^{-1}\right)$

Calcium (mg dL $\left.{ }^{-1}\right)$

$\begin{array}{ll}\text { Olive oil } & \text { Testosteron } \\ 302 \pm 37.0^{\mathrm{B}} & 787 \pm 188^{\mathrm{A}}\end{array}$

$406 \pm 35.8^{\mathrm{B}} \quad 1090 \pm 280^{\mathrm{A}}$

$32.5 \pm 1.02^{\mathrm{A}} \quad 28.8 \pm 2.43^{\mathrm{A}}$

$72.4 \pm 1.97^{\mathrm{B}} \quad 114 \pm 16.2^{\mathrm{A}}$

$300 \pm 19.0^{\mathrm{A}} \quad 302 \pm 21.2^{\mathrm{A}}$

$37.2 \pm 1.16^{\mathrm{A}} \quad 37.7 \pm 1.14^{\mathrm{A}}$

$0.52 \pm 0.01^{\mathrm{A}} \quad 0.43 \pm 0.01^{\mathrm{B}}$

$60.4 \pm 6.17^{\mathrm{A}} \quad 62.5 \pm 4.70^{\mathrm{A}}$

$47.2 \pm 1.71^{\mathrm{A}} \quad 45.4 \pm 2.35^{\mathrm{A}}$

$29.8 \pm 1.60^{\mathrm{A}} \quad 25.0 \pm 1.74^{\mathrm{A}}$

$926 \pm 54.4^{\mathrm{A}} \quad 892 \pm 29.0^{\mathrm{A}}$

$\begin{array}{ll}6.17 \pm 0.13^{\mathrm{A}} & 5.30 \pm 0.20^{\mathrm{B}}\end{array}$

$3.51 \pm 0.12^{\mathrm{A}} \quad 3.02 \pm 0.09^{\mathrm{B}}$

\begin{tabular}{rr}
$9.80 \pm 0.11^{\wedge}$ & $8.11 \pm 0.22$ \\
\hline${ }^{A}$ different &
\end{tabular} t-test)

albumin, calcium and creatinine levels $(p<0.05)$, it increased AST, CK-MB and CK levels $(\mathrm{p}<0.05)$. AAS, due to their anabolic features have been used for the treatment of some diseases since 1940s (Kerr and Congeni, 2007).

However, AAS have been abused by the sportspeople (Handelsman and Gupta, 1997). In the present study it was determined that testosterone had increased serum $\mathrm{CK}$ and $\mathrm{CK}-\mathrm{MB}$ level of the male rats during puberty $(\mathrm{p}<0.05)$ (Table 1$)$. Similarly, in weight lifters and body builders who had anabolic hormone reinforcement increase has been observed at CK levels (Hakkinen and Alen, 1989). Total CK levels change according to age, sex, race, muscle mass, physical activity and climate conditions (Brancaccio et al., 2007). Serum CK and its isoenzymes are used for the diagnosis of common cardiomyopathy, ensefalofati and muscle diseases, $\mathrm{CK}-\mathrm{MB}$ is generally used for the diagnosis of cardiac injury (Brancaccio et al., 2006). In the literature, no information has been encountered about the effects of testosterone usage during puberty on serum $\mathrm{CK}$ and CK-MB activities. Long term testosterone and AAS usage during puberty can be thought to lead to muscle and heart injury. AST is accepted as one of the liver injury indicators and it is reported that increases have been observed when necrosis develop in hepatocytes. In the present study, it has been determined that testosterone has increased AST level $(\mathrm{p}<0.05)$ (Table 1). In the researches where the effects of AASs on liver have been examined, it has been reported that these levels have increased for those who take AAS for a few weeks (Hartgens and Kuipers, 2004; Vieira et al., 2008). It has been reported that there has been increases on the AST levels of the body builders who take anabolic steroid (Dickerman et al., 1999). This leads to the result that long term AAS usage in men during puberty may result in liver 
injury. In the present study, it has been determined that testosterone application has decreased serum total protein and albumin levels $(\mathrm{p}<0.05)$ (Table 1). Similarly, it has been determined that serum total protein level has decreased in nandrolon treated rats (Vieira et al., 2008). It has been reported that liver protein synthesis has decreased in patients with chronic liver disease. In the present study when high AST level is accepted as liver injury indicator, it can be stated that the decrease in the protein synthesis may develop due to liver injury. Although, creatinine and calcium levels decreased and there was meaningful difference, numerical data in the results was defined to be between reference ranges (Table 1).

\section{CONCLUSION}

As a result, it can be stated that long term AAS usage during puberty may lead to heart, muscle and liver diseases at early ages.

\section{REFERENCES}

Bartley, J.C., 1989. Lipid Metabolism and its Diseases. In: Clinical Biochemistry of Domestic Animals, Kaneko, J.J. (Ed.). Academic Press Inc., London, pp: 106-141 .

Bhasin, S., T.W. Storer, N. Berman, C. Callegari and B. Clevenger et al., 1996. The effects of supraphysiologic doses of testosterone On muscle size and strength in normal men. N. Engl. J. Med., 335: $1-7$.

Brancaccio, P., N. Maffulli and F.M. Limongelli, 2006. Monitoring of serum enzymes in sport. Br. J. Sports Med., 40: 96-97.

Brancaccio, P., N. Maffulli and F.M. Limongelli, 2007. Creatine kinase monitoring in sport medicine. Br. Med. Bull., 81: 209-230.

Bukowski, C., M.A. Grigg and C. Longcope, 2000. Sex hormone-binding globulin concentration: Differences among commercially available methods. Clin. Chem., 46: 1415-1416.

Casavant, M.J., K. Blake, J. Griffith, A. Yates and L.M. Copley, 2007. Consequences of use on anabolic androgenic steroids. Pediatric Clin. North Am., 54: $677-690$.
Dickerman, R.D., R.M. Petrusi, N.Y. Zachariah, D.R. Dufour and W.J. McConathy, 1999. Anabolic steroid-induced hepatotoxicity: Is it overstad?. Clin. J. Sport Med., 9: 34-39.

Dotson, J.L. and R.T. Brown, 2007. The history of the development of anabolic-androgenic steroids. Pediatr. Clin. North Am., 54: 761-769.

Finco, D.R., 1989. Kidney Function. In: Cilinical Biochemistery of Domestic animals, Kaneko, J.J. (Ed.). 4th Edn., Academic Press, London, UK., pp: 524-537.

Hakkinen, K. and M. Alen, 1989. Training volume, androgen use and serum creatine kinase activity. Br. J. Sports Med., 23: 188-189.

Handelsman, D.J. and L. Gupta, 1997. Prevalence and risk factors for anabolic-androgenic steroid abuse in Australian high school students. Int. J. Androl., 20: 159-164.

Handelsman, D.J., 2006. Testosterone: Use, misuse and abuse. MJA, 185: 436-439.

Hartgens, F. and H. Kuipers, 2004. Effects of Androgenic-anabolic steroids in athletes. J. Sport Med., 34: 513-522.

Kerr, J.M. and J.A. Congeni, 2007. Anabolic-androgenic steroids: Use and abuse in pediatric patients. Pediatr. Clin. North Am., 54: 771-785.

Kramer, J.W., 1989. Clinical Enzymology. In: Cilinical Biochemistery of Domestic Animals, Kaneko, J.J. (Ed.). 4th Edn., Academic Press, London, UK., pp: 352-360.

Marshall-Grandisnik, S., R. Green, E.W. Brenu and R.P. Weatherby, 2009. Anabolic androgenic steroids effects on the immune system: A review. Central Eur. J. Biol., 4: 19-33.

Vardar, E., S.A. Vardar and C. Tuglu, 2002. Anabolikandrojenik steroidlerin kötüye kullanimi. Anadolu Psikiyatri Dergisi, 3: 104-107.

Vieira, R.P., R.F. Franca, N.R. Damaceno-Rodrigues, M. Dolhnikoff, E.G. Caldini, C.R.F. Carvalho and W. Ribeiro, 2008. Dose-dependent hepatic response to subchronic administration of nandrolone decanoate. Med. Sci. Sport Exercise, 40: 842-847.

Wu, F.C.W., 1997. Endocrine aspects of anabolic steroids. Clin. Chem., 43: 1289-1292. 